IZA DP No. 2518

Workplace Industrial Relations in Britain, 1980-2004

David G. Blanchflower

Alex Bryson

John Forth

December 2006 


\title{
Workplace Industrial Relations in Britain, 1980-2004
}

\author{
David G. Blanchflower \\ Dartmouth College, NBER, \\ Bank of England and IZA Bonn \\ Alex Bryson \\ Policy Studies Institute \\ and Centre for Economic Performance \\ John Forth \\ National Institute of Economic and Social Research
}

\author{
Discussion Paper No. 2518 \\ December 2006
}

\author{
IZA \\ P.O. Box 7240 \\ 53072 Bonn \\ Germany \\ Phone: $+49-228-3894-0$ \\ Fax: +49-228-3894-180 \\ E-mail: iza@iza.org
}

\begin{abstract}
Any opinions expressed here are those of the author(s) and not those of the institute. Research disseminated by IZA may include views on policy, but the institute itself takes no institutional policy positions.

The Institute for the Study of Labor (IZA) in Bonn is a local and virtual international research center and a place of communication between science, politics and business. IZA is an independent nonprofit company supported by Deutsche Post World Net. The center is associated with the University of Bonn and offers a stimulating research environment through its research networks, research support, and visitors and doctoral programs. IZA engages in (i) original and internationally competitive research in all fields of labor economics, (ii) development of policy concepts, and (iii) dissemination of research results and concepts to the interested public.
\end{abstract}

IZA Discussion Papers often represent preliminary work and are circulated to encourage discussion. Citation of such a paper should account for its provisional character. A revised version may be available directly from the author. 


\section{ABSTRACT}

\section{Workplace Industrial Relations in Britain, 1980-2004*}

There was a time before the first Workplace Industrial Relations Survey (WIRS80) in 1980 when what we knew of industrial relations was based primarily upon small scale surveys and case studies. WIRS80 marked a radical departure in the study of industrial relations for two reasons. First, following in the footsteps of a small number of survey forerunners, it sought to 'map' industrial relations in Britain with nationally-representative large-scale surveys of workplace managers, thus permitting investigation of the incidence of practices and changes over time. Second, it focused on industrial relations institutions and outcomes, linking them to the processes of industrial relations that had been the chief focus of studies up until that point. This paper reflects on some of what we have learned in the five surveys over the quarter century since 1980, focusing selectively on the demise of collective IR, pay determination, union wage effects, variable pay, the climate of employment relations and union effects on employment growth.

JEL Classification: J51

Keywords: $\quad$ trade unions, wages, employment, growth

Corresponding author:

David G. Blanchflower

Department of Economics

6106 Rockefeller Hall

Dartmouth College

Hanover, NH 03755-3514

USA

E-mail: blanchflower@dartmouth.edu

\footnotetext{
* We thank the ESRC for financial support (grant RES-000-23-1603). We acknowledge the Department of Trade and Industry, the Economic and Social Research Council, the Advisory, Conciliation and Arbitration Service and the Policy Studies Institute as the originators of the Workplace Industrial Relations Surveys (WIRS) and the Data Archive at the University of Essex as the distributor of the data. None of these organizations or individuals bears any responsibility for the authors' analysis and interpretations of the data.
} 


\section{In the beginning....}

The first attempt to identify the contours of industrial relations (IR) with largescale nationally-representative surveys of workplaces in Britain was made by the Royal Commission on Trade Unions and Employers' Associations - the Donovan Commission - in 1966 (Government Social Survey, 1968). Others followed, notably follow ups to the Donovan Commission's surveys in 1972 and 1973 (Parker, 1974; Parker, 1975), Daniel's (1976) PEP survey of workplace wage determination and the Warwick Workplace Survey of 1977-8 (Brown, 1981). But large-scale surveys of IR provided the basis for relatively little academic investigation in Britain in the 1960s and 1970s. The empirical basis for the discipline consisted largely of case studies and small scale surveys mostly confined to manufacturing. This all changed with the Workplace Industrial Relations Survey 1980 (WIRS80).

In the forward to the WIRS84 sourcebook Peter Brannen, one of the originators of the WIRS series, explained how WIRS was first conceived:

“The first systematic survey of employment relations issues was undertaken for the Donovan Commission. Two other national surveys followed shortly afterwards. But these surveys never became part of a systematic series. The idea of establishing a series of Workplace Industrial Relations Surveys was developed in the late 1970s in the Department of Employment to remedy this lack of systematic data and to make possible the analysis of change and continuity over time” (Millward and Stevens, 1986: x).

All national, employer-based surveys have some aims in common. As Millward, Marginson and Callus (1998: 137) point out, they provide a 'snapshot of the structures, practices and outcomes of industrial relations'; identify diversity and heterogeneity within employer populations; offer opportunities for hypothesis testing and theory building; provide data for policy evaluation; and, if repeated over time, can map change and identify reasons for it. Their methodological strength is in offering generalizability and transparency (Marginson, 1998). WIRS80 was no different in these respects. What did make it different was its cosponsorship by government (Department of Employment), the academic community (the Social Science Research Council, the forerunner to the Economic and Social Research Council) and the Policy Studies Institute (PSI). ${ }^{1}$ The Department's interest was 'to ensure that there was established a solid base for analysis of industrial relations practice and procedures as a background for policy making' (Daniel and Millward, 1983: 2). SSRC's aim was 'to ensure that a rich, new data base about industrial relations was made available to the whole community of researchers and scholars in a form that was most useful to them'

\footnotetext{
${ }^{1}$ From 1984 the Advisory, Conciliation and Arbitration Service (ACAS) has been the fourth cosponsor of WERS.
} 
(op. cit.). PSI was concerned 'that the information be used for medium term policy analysis and evaluation’ (op. cit.).

For Marginson (1998: 362) the commonalities in purpose - 'to provide a detailed account of workplace industrial relations that was nationally representative' - and design 'mark out the workplace survey undertaken for the Royal Commission as the forerunner of the WIRS series'. But it was Daniel (1976) that was the immediate forerunner to WIRS80 and is perhaps the survey that most heavily influenced WIRS in its design and execution. Describing with enthusiasm the PEP 1976 survey, Daniel says:

"This is the first time that the sample survey method, based on personal interviews with management and union representatives, has been used...to contribute towards an understanding and explanation of the process of labour relations, rather than simply describing its institutions” (Daniel, 1976: 1).

The PEP survey was indeed path-breaking in using nationally-representative data to look at ways in which pay and pay increases are determined at work. At the time it was perfectly reasonable to focus on the manufacturing sector because it accounted for a much larger proportion of the British economy than it does today. In 1978, 7.1m jobs (27 per cent of the UK total) were located in manufacturing, compared with 3.3m (11 per cent) in 2006. (Source: ONS). It was also natural for the survey to concentrate on pay determination through collective bargaining, since this was the dominant form of pay setting in manufacturing. The chief concern at the time was the desire to map both 'formal' workplace-level bargaining plus 'the more informal shop floor bargaining over rates for the job under payments for results and other types of special or premium payment, at a lower level, and the company and industry bargaining at a higher level' (p.2). In other words, Daniel was keen to reflect the complexity of collective bargaining over pay, a system that had been carefully depicted by the Donovan Commission in the late 1960s. This focus on manufacturing and on collective bargaining led inexorably to a focus on plant-level analysis because 'this is generally the most important level of formal bargaining for manufacturing' (p.2). This survey was an important influence on the development of WIRS in terms of the primary unit of analysis (the workplace) and, at least in the early years, the concentration on the institutions of industrial relations. Other important influences on the unit of analysis were the requirement for a defined statistical unit that could be sampled from a good quality sampling frame (see Millward, 1991), and a primary concern with the practice of employment relations rather than avowed policies. The limitations of the PEP survey also influenced thinking on WIRS, especially Daniel's remarks that the small sample size was 'frustrating' and 'exasperating', amply illustrated with examples he presents on the first page of the report.

WIRS surveys have now been conducted five times (1980, 1984, 1990, 1998, 2004), but it is easy to understate the ambition and potential risks associated with 
the first survey in 1980. As Cully (1998) reminds us, OPCS senior statisticians had advised against WIRS80 saying that 'a survey which takes establishments as its unit of analysis will not succeed in its research aims....[due] to the unreliability of information obtained from individuals acting as proxy informants'. Furthermore, it was a far more ambitious enterprise than any workplace survey undertaken hitherto. The three earlier surveys had been confined to manufacturing workplaces and had focused on large establishments the size thresholds being 50, 150 and 200 employees in the case of the Warwick survey, the 1966 Donovan survey and the PEP survey respectively. The Donovan followups in 1972 and 1973 had a minimum threshold of 250 employees for most sectors. WIRS80, in contrast, covered the whole economy (manufacturing, private services and the public sector) and lowered the employment threshold to workplaces with 25 or more employees (full or part-time). ${ }^{3}$ Another major difference was that the data was made publicly available for secondary analysis.

The resultant WIRS80 survey was also challenging from an analysts' perspective. The computer technology we take for granted today when crunching large data files was only just emerging at the time, with analysts relying on slow mainframes to process data held on magnetic tapes. There were few canned software packages and researchers frequently had to write their own programs. The other challenge was one of interpretation and understanding, especially in relation to private services and the public sector where there was little or no large-scale data with which to compare the results.

Industrial relations (IR) was very different a quarter of a century ago, as we all know, but perhaps we forget just how different. As Daniel and Millward (1983: 1) note in their opening paragraph, IR had 'been at the forefront of public and political debate in Britain' for the previous two decades and 'reform of the industrial relations system had been part of every political party's manifesto'. This is because IR was viewed as a serious problem, its turbulence contributing to macro-economic problems and difficulties for firms, workers and their families. This impact is amply illustrated by Daniel's reflections on the effect that turbulent IR had on PEP's ability to conduct its workplace manufacturing survey in 1976. "We had wanted in our study to look at plant negotiations under the normal process of collective bargaining", says Daniel plaintively, recalling just how difficult this had been due to Conservative incomes policy, the three day week, 'then a period of sorting out the aftermath of both of these', followed by the new $£ 6.00$ pay limit policy (Daniel, 1976: 2-3). If anything, things deteriorated in the period prior to WIRS80, culminating in the Winter of Discontent in 1979, the year

\footnotetext{
${ }^{2}$ Letter from Head of Social Survey Division, OPCS, July 1979, Department of Trade and Industry files. The counter argument, and the means of addressing situations in which a workplace manager is not suitably informed, are discussed by Millward (1991: 140-150).

${ }^{3}$ This coverage was made possible by a better sampling frame, the Census of Employment (Daniel and Millward, 1983: 5-6).
} 
in which union density and union membership peaked in Britain (Blanchflower, 2007).

If we fast forward some 25 years, there are two obvious points to make about WIRS today. First, there is a general acceptance of the value of large-scale survey data collection in furthering our understanding of IR. It is not without its critics, of course (McCarthy, 1994; Blackburn, 2005). Although there is general consensus that large-scale surveys are complements to case-study and other methodologies in investigating IR, there may be some justification for the view that large-scale data collection and analysis are 'crowding out' case-study investigation of IR to the detriment of the discipline (Marginson, 1998). It is evident, however, that even in area of large-scale surveys WIRS is no longer the only game in town. The Warwick Company Level Industrial Relations Surveys (CLIRS) have provided what Marginson (1998: 364) refers to as 'a complementary comprehensive portrait of industrial relations structures, practices and policy formation beyond the workplace among large enterprises across the trading sector of the economy'; and there has been an explosion in government evaluation surveys, many of which are workplace-based. Other academic surveys have included those co-ordinated by Michael White for the ESRC's Social Change and Economic Life Initiative (see Gallie, 1994: 362-5) and the Future of Work Programme (White et al, 2004), whilst there has also been an increase in government evaluation surveys, many of which are workplace-based (e.g. Woodland et al, 2003).

Second, there has been a seismic shift in the discipline reflecting changes in IR structures and practice, embodied in the change in the survey's name from WIRS to WERS. In essence these changes are two-fold. The first is the movement away from joint regulation to the restoration of managerial prerogative and the reemergence of the 'managerialist' HRM agenda. The second shift has been towards much greater interest in employees' experience of work in its own right. WIRS has reflected these trends with a very substantial shift in the nature of the survey instruments and survey design (Cully and Marginson, 1995; Cully, 1998; Marginson, 1998; Marginson and Wood, 2000; Kersley et al., 2006). The everchanging nature of WIRS reflects an abiding concern with continuity and change. Identifying the degree of continuity in IR means retaining a core set of questions which permit the construction of time-series data. Identifying the nature and reasons for change entails innovation in survey questioning and design. This was apparent to the inventors of WIRS at the outset. Introducing the WIRS84 book, Peter Brannen says that it "provides a comprehensive overview and descriptive analysis of the survey data and sets out in a lucid and objective manner a wealth of material on employment and industrial relations in British workplaces...More importantly, however, the authors have been able to identify, in a rigorous manner, changes and developments over the previous years. This is the first time that such systematic monitoring has been possible' (Millward and Stevens, 1986: xi,). Brannen explains that, in order to achieve this, 'a substantial core of common questions was retained but a new topic area, concerned with technical 
change, was introduced...In addition an experimental panel element was built into the design.' And so the state of permanent revolution which is the WIRS series got underway. This 'revolution' has subsequently involved the refinement and extension of the panel survey a new employee survey linked to workplaces introduced in 1998 and extended in 2004, the linkage of the survey data to financial information in the Annual Business Inquiry (Kersley et al., 2006), the interviewing of non-union worker representatives in 2004, and a reduction in the employment size threshold for inclusion in the survey from 25 employees to 10 in 1998 and 5 in 2004 (Forth et al., 2006).

In the remainder of this paper we focus on WIRS' treatment of the following substantive themes, which have featured prominently in primary and secondary analysis of the data throughout the survey series:

- the demise of collective IR

- pay determination and union wage effects

- pay settlements

- variable pay

- the climate of employment relations

- and union effects on employment growth.

In doing so, we draw on the primary sourcebooks and some of the secondary analyses that appeared in academic journals. Our intention is to reflect on how WIRS marked such an important departure in the study of IR.

\section{The Demise of Collective Industrial Relations}

Reflecting on changes in industrial relations traced with the first four WIRS surveys (1980, 1984, 1990 and 1998) Millward et al. (2000: 234) proclaimed the end of collective industrial relations in Britain:

"The Conservative government that came to power in 1979 confronted a system of collective employment relations that was dominant, though not universal...That system of collective relations, based on the shared values of the legitimacy of representation by independent trade unions and of joint regulation, crumbled in the intervening eighteen years to such an extent that it no longer represents a dominant model”.

They maintained that this change was so profound that it 'can reasonably be regarded as a transformation' (op. cit.). Union membership and density had 
peaked in 1979 (Charlwood and Metcalf, 2005). Comparisons of WIRS80 with earlier IR surveys had indicated a 'growth in the formality of workplace industrial relations' (Daniel and Millward, 1983: 296) as advocated by the Donovan Commission. Despite Thatcher's first term in office, WIRS measures of collective IR were fairly stable between 1980 and 1984 (Millward and Stevens, 1986: 302-305) with workplace union recognition actually rising in the economy as a whole (Millward and Stevens: 1986: 62-63). Yet even in 1984 there were signs of change with decline in the closed shop and in union presence (any members on-site) and a fall in union recognition in manufacturing (Millward and Stevens, 1986). This took commentators at the time by surprise. ${ }^{4}$ But it was only when comparing WIRS84 with WIRS90, that analysts became aware of just how much had changed over a very short period. The authors argued 'so great were the changes that it is not unreasonable to conclude that the traditional, distinctive "system" of British industrial relations no longer characterized the economy as a whole' (Millward et al., 1992: 350). Purcell (1993) called it 'the end of institutional industrial relations'.

For many years it had been possible to track changes in union membership with data lodged with the Certification Officer by trade unions. One-off surveys of individuals such as the National Training Survey 1975 also contained union membership, but it was only later that repeat cross-section surveys of individuals permitted analyses of changes in union membership. British Social Attitudes (BSA) was among the first, collecting union membership data from $1983 .{ }^{5}$ WIRS' unique contribution was three-fold. First, WIRS provided data on workplace density, giving a better indication of the concentration of union membership and power than is possible with individual-level data. Second, it tracked change in workplace-level institutions, notably union recognition, the preand post-entry closed shop, bargaining structures (multiple versus singleunionism and, where multiple unions existed, the use of joint versus separate bargaining arrangements), the presence of on- and off-site worker representatives, workplace union density and collective bargaining coverage and the scope of collective bargaining. Most of these items were present from the outset. They have been added to subsequently with measures such as occupation-level collective bargaining coverage within workplaces, occupation-level union membership presence, employer perceptions of unions' roles and, with the advent

\footnotetext{
${ }^{4}$ For example, Willie Brown, writing just before the release of Millward and Stevens (1986) had said: "Although, for the British economy as a whole, the level of unionization has fallen substantially during the recession, from 55 per cent in 1979 to around 45 per cent now (the level at which it remained throughout the 1950s and 1960s), it is hard to see it fall much further, so well entrenched is the practice of collective bargaining and, with it, closed shop and check-off arrangements” (Brown, 1986: 167).

${ }^{5}$ Other early studies containing union membership information include the General Household Survey, the National Child Development Survey and the British General Election Survey. The Labour Force Survey collected membership data from 1989. BHPS has collected it since it began in 1992.
} 
of linked data from employees, individual worker union membership. The third unique contribution was its ability to identify union effects on outcomes such as wages, productivity, climate, employment growth and financial performance. (We discuss union effects on wages and employment growth later).

Collective IR in Britain rested on employers' voluntary recognition of unions for pay bargaining. ${ }^{6}$ Since this decision was usually made at workplace-level or, if made at organization-level, was devolved to workplace-level, it made sense to talk of union recognition as a workplace attribute. Yet this concept of workplacelevel union recognition only really entered the IR lexicon with WIRS. The difficulty with reliance on coverage by a collective bargaining agreement was that since most were, at the time, multi-employer agreements, it was unclear how they related to workplace-level industrial relations. Studies had indicated nominal coverage in many cases and managerial difficulties in accurately identifying whether their workplace was covered or not.

Certainly in those early days of WIRS, union recognition was a good indicator of union activity on the ground at the workplace, but it was by no means the only important measure. The IR literature had shown how differently unions operated in the presence of an on-site lay official, and according to whether or not that representative was full-time or part-time (McCarthy, 1967). Labour economists were keen to exploit information indicating the degree of strength unions had when restricting the supply of labour to employers. This bargaining strength was often proxied by WIRS indicators of union density, multi-unionism and the presence of pre- and post-entry closed shops.

In recent years union recognition for pay bargaining has become a less reliable indicator of union activity at workplace-level due to the 'hollowing out' of unionization even where a union is present. This first became apparent with WERS98 when sourcebook analysts uncovered a high percentage of workplaces with union recognition where there appeared to be no collective bargaining coverage (Millward et al., 2000: 159-167). This 'hollow shell' phenomenon, also uncovered in case study work by Brown et al. (1998), was apparent once again in WERS04, extending to all aspects of joint regulation, not just pay determination (Kersley et al., 2006: 193-6). It is also apparent in the precipitous decline of union membership within unionized workplaces. The rate of union density decline within recognized workplaces rose three-fold in the 1990s compared to the second half of the 1980s (Millward et al., 2000: 139-145) resulting in substantial growth in free-riding (Bryson and Freeman, 2006a).

IR analysts and commentators became so used to union decline in the 1980s and 1990s that they had come to expect it. This decline took two forms: a reduction in the incidence of unionization in the workplace population and, where it continued

\footnotetext{
${ }^{6}$ This remains the case in spite of the statutory recognition procedure introduced by the Employment Relations Act 1999.
} 
to exist, a diminution in its reach and strength. From the mid-1980s there was a precipitous decline in union recognition, the closed shop, and workplace multiunionism (Millward et al., 2000). The decline in union recognition continued into the 1990s, albeit at a slower rate, but this decline has ceased since 1998, at least among the traditional population of workplaces with 25 or more employees (Table 1). ${ }^{7}$ The decline in a couple of percentage points is not statistically significant. This may reflect the importance of the political and policy climate under New Labour (Kersley et al., 2006; Bryson, 2006a). ${ }^{8}$ There is also a surprise in Table 1, namely the rise in union recognition rates in the shrinking private manufacturing sector.

This slow down in the rate of decline in collective IR, confirmed in other research pointing to an increase in the rate of new union recognitions (Gall, 2004; Blanden et al., 2006), is also apparent in the slower rate at which collective bargaining coverage has fallen since 1998, but again there are large sectoral differences with the rate of decline greatest in private manufacturing (Kersley et al., 2006: 187188). ${ }^{9}$

One could nevertheless argue that, by the turn of the century, the strongest forms of unionization - especially the closed shop - had all but disappeared in Britain, at least in the private sector. One-in-five private manufacturing workplaces with 25 or more employees recognizing unions for bargaining scored a maximum of three points on Millward et al.'s (2000: 179-183) index of union strength by 1998, as did one-in-seven private service workplaces recognizing unions. ${ }^{10}$ The closed shop had effectively been outlawed in Britain by 1990 so it was not surprising to see that it had virtually disappeared by 1998 (Millward et al., 2000: 147). Only 3 per cent of workplaces with 5 or more employees had 100 per cent union membership in WERS04. Among workplaces with union members who recognized unions and had 25 or more employees, the percentage with 100 per cent union membership fell from 19 per cent in 1984 to 13 per cent in 1990 to 4 per cent in 1998 (Millward et al., 2000: 140). By 2004 the figure stood at 6 per cent.

\footnotetext{
${ }^{7}$ An employer may recognize a union for pay bargaining such that the union bargains over wages, even when there are no union members present on the site. This phenomenon was only tracked in WERS for the first time in 2005, indicating that 3 per cent of all workplaces - or one-tenth of those recognizing unions - 'would not have been identified as recognizing unions in earlier surveys in the series' (Kersley et al., 2006: 120).

${ }^{8}$ Union recognition did decline between 1998 and 2004 in workplaces with 10-24 employees (Kersley et al., 2006: 120).

${ }^{9}$ These figures on collective bargaining coverage relate to the population of workplaces with 10 or more employees, whereas the figures on union recognition in the previous paragraph relate to the population of workplaces with 25 or more employees.

${ }^{10}$ Workplaces scored a point for each of the following: union density of $75 \%$ or more, an on-site lay union representative, and collective bargaining coverage of $80 \%$ or more.
} 
It is one thing to 'map' the demise of collective industrial relations, quite another to seek to explain it. Surveys of individual employees were able to take analysts so far. For example, they were useful in identifying the role played by compositional change in the workforce. Studies such as Bryson and Gomez (2002) showed that compositional change in the workforce accounted for only a minority of the decline in union membership. They also showed that the stock of members had declined due to a rise in the percentage of employees who had never joined a union, as opposed to an increase in the rate of exit from membership (Bryson and Gomez, 2005). By 2005 never-membership accounted for just over half of employees in employment (Bryson, 2006a). However, WIRS allowed for unique in-sights for two reasons. First, it was able to track change in collective IR alongside managerial attitudes to unionization. Second, it combined crosssectional and panel workplace data allowing analysts to identify the extent to which union decline was due to changes in the composition of workplaces, on the one hand, and behavioural change among surviving workplaces on the other.

The decline in the incidence of collective IR across the economy was due, in large part, to a cohort effect, rather than behavioural change among surviving workplaces. Newer workplaces had a lower propensity to unionize than older ones, with evidence pointing to a 'golden age for union recognition.....during the Second World War and the years immediately following it' (Millward et al., 2000: 103). ${ }^{11}$ Instead, newer workplaces have adopted non-union forms of voice, usually direct two-way forms of communication (Willman et al., 2006a). Union workplaces, on the other hand, have largely eschewed full union de-recognition but have increasingly supplemented union voice with non-union voice (op. cit.). Successive cohorts of individuals were also less likely to join unions (Blanchflower, 2007).

Across the economy as a whole, the percentage of 'no voice' workplaces has remained constant since the mid-1980s at around one-sixth (Bryson et al., 2004; Willman et al., 2006b), casting doubt on concerns about the growth in 'bleak house' IR. Between 1998 and 2004 patterns of change shifted. The union recognition rate among panel workplaces with 10 or more employees who were in existence throughout the period was stable. Recognition was also more or less stable among workplaces with 25 or more employees in the 1998 and 2004 crosssectional data. However, union recognition fell quite dramatically among the smallest workplaces with 10-24 employees. Nevertheless new workplaces remained steadfastly non-union - their union recognition rates were far lower than older workplaces and those that had closed over the period (Kersley et al., 2006: 120-121).

WIRS also cast light on what happened within the union sector. By assessing the decline in union density across workplaces with different levels of managerial support, Millward et al. (2000: 150-2) were able to show that "the decline in the

\footnotetext{
${ }^{11}$ Machin (2000) reports similar findings also using WERS data.
} 
closed shop and strong management endorsement of membership were the main reasons for the fall in mean union density in unionized workplaces between 1984 and 1990." However, the picture was "quite different" for the period 1990 to 1998 when "employees appeared to have lost their appetite for unionism." In essence, in the 1980s unions lost the support of government and managers, whereas in the 1990s "they also lost the support of many employees." Managers' attitudes towards unions remained unchanged over the period 1998-2004 (Kersley et al., 2006: 114-115) but there are signs that the rapid growth in free-riding in the 1980s has ceased (Bryson, 2006a).

Whereas collective IR remained strong in the public sector, analyses of WIRS 1984-1998 indicated that changes in the types of workplace entering and leaving the population played only a minor role in the demise of collective IR in the private sector (Bryson et al., 2004). Rather, the decline was widespread, a cohort effect affecting most types of workplace, with newer workplaces entering the population increasingly likely to be non-union relative to their older counterparts, regardless of their other characteristics (Millward et al., 2000; Millward, 1994).

\section{Pay determination and the union wage premium}

We have already alluded to the fact that the decline in collective IR substantially diminished the role of collective bargaining in setting pay for employees in Britain due to the declining reach of trade unions and even where unions were present. Among the traditional WIRS population of workplaces with 25 or more employees, the incidence of collective bargaining remained roughly constant between 1998 and 2004 in the economy as a whole, with around four-in-ten workplaces using collective bargaining for at least some of their workers (Kersley et al., 2006: 186). The rate of decline in aggregate collective bargaining coverage in the economy as a whole has slowed since 1998 compared to the 1980s and 1990s but this hides big differences in sectoral trends. The percentage of employees in private manufacturing covered by collective bargaining fell at twice the rate in 1998-2004 compared to 1990-98 and was identical to the rate of decline for the 1984-90 period. In private services, on the other hand, the rate of decline has slowed, albeit from a lower base. Collective bargaining coverage in the public sector has actually risen since 1998, largely due to collective bargaining over re-grading and pay in the health sector (Kersley et al., 2006: 187188).

The traditional WIRS population of workplaces with 25 or more employees overstates the prevalence of collective bargaining in the economy. Only one-ineight private sector workplaces with 5 or more employees had any collective bargaining in 2004. These workplaces were predominantly the larger workplaces so that one-quarter of employees were located in them (Forth et al., 2006: 57-59). Nearly three-quarters (73 percent) of employees in private sector workplaces with 5 or more employees had their pay set unilaterally by management - usually at 
workplace level (op. cit.). Only a handful (5 percent) negotiated their pay individually with management.

This diminution in collective bargaining coverage has had a profound effect on pay outcomes. A priori it is unclear what the net effect of unions might be on the pay distribution. ${ }^{12}$ In fact, declining unionisation has contributed substantially to rising wage inequality among men but not among women (Card, Lemieux and Riddell, 2003). Where collective bargaining occurred in 2004 it continued to have a substantial impact in compressing pay at workplace level (Kersley et al., 2004:198) and in reducing the incidence of low pay (Kersley et al., 2004: 199200). ${ }^{13}$ Collective bargaining was also able to deliver a fringe benefits premium (op.cit.), as was the case in WERS98 (Forth and Millward, 2002a). In addition to these studies estimating the direct effects of collective bargaining, Belfield and Heywood (2001) used WERS98 to estimate indirect effects of unions on dispersion in the non-union sector due to unionization 'threat effects'. They found the estimated probability of unionization had a negative but statistically non-significant effect on workplace-level wage dispersion in the non-union sector.

One of WIRS' biggest contributions to our understanding of IR has been in the estimation of the union wage premium. Early WIRS studies marked a big advance on previous studies. First, ceteris paribus estimates of the union wage premium could be made more accurately through comparisons of union and nonunion workplaces, rather than the aggregate-level analyses that had preceded it. In particular, earlier inter-industry studies had overestimated the size of the union wage premium due to difficulties controlling for inter-industry differences in workplace characteristics (Blanchflower, 1984). Second, WIRS offered a range of unionisation measures which meant that analysts could test the sensitivity of their results to different institutional facets of workplace arrangements. This was particularly valuable since some WIRS variables - notably the closed shop and union density - were thought to be good proxies for the degree to which unions could monopolise the supply of labour to employers, this monopolisation being the source of their bargaining power (Stewart, 1987).

Blanchflower's (1984) paper analyzing the union wage premium among manual workers with WIRS80 was the first to use workplace-level data in Britain ${ }^{14}$ and,

\footnotetext{
${ }^{12}$ Their pursuit of 'standard' rates for jobs is a force for pay equalization, as is the threat of unionization which forces non-union employers to raise pay or benefits to keep unions out. On the other hand, they bargain for higher rates for their members relative to non-members. Thus their impact on the wage distribution will depend, in large part, on how many workers they organize, which workers they organize, and variation in the wage premium across workers.

${ }^{13}$ This 'sword of justice' effect of union pay bargaining has been verified using other data sources such as the Labour Force Survey and has been estimated to have a much bigger impact on the gender pay gap than the introduction of the national minimum wage (Metcalf, 2005).

${ }^{14}$ Blanchflower (1984: 328) cites some earlier studies using establishment micro-data in the USA.
} 
in covering semi-skilled and skilled manual workers in manufacturing, nonmanufacturing and the whole economy, it was far more comprehensive than any previous analysis for Britain. It was also the first econometric analysis to make use of the concept of union recognition rather than union density or coverage. He cites thirteen previous studies for the Britain, four of which use union membership as a measure of unionization, with the remainder using coverage by collective bargaining agreement. Blanchflower argues that estimates based on WIRS80 are less likely to be biased than previous estimates for two reasons. First, he uses workplace-level union recognition which, he maintains, is less prone to measurement error in a survey of personnel managers (Blanchflower, 1984: 322). ${ }^{15}$ Second, he uses micro-data as opposed to the aggregate data used in all but one of the previous studies permitting the inclusion of a richer array of control variables and the avoidance of aggregation bias emanating from variation in union differentials across industries. ${ }^{16}$ His estimates of the union wage premium are lower than those using aggregate data and are larger for semi-skilled manual workers than for skilled manual workers. The paper also identifies a higher premium in the non-manufacturing sector which had not been identified to that point. The operation of union variables was also found to differ across sectors, with workplace-level union recognition and multi-unionism associated with higher wages in non-manufacturing whereas in manufacturing it was industrylevel unionization that mattered. Blanchflower and Oswald (1990a) performed a similar analysis for white-collar workers.

WIRS studies have consistently demonstrated that the size of the union premium is correlated with the ability of unions to monopolise the supply of labour and that, where unions are weaker there is often no premium at all. For instance, Stewart (1987) found the workplace-level union recognition premium for skilled manual workers in WIRS80 was confined to those working in establishments with a closed shop. In a subsequent paper, Stewart (1995) attributes part of the decline

\footnotetext{
15 The reason why so much of the existing literature uses union membership, rather than bargaining coverage, to estimate union effects, is that coverage measures are usually absent or assumed to be measured with error. Surveys of individual employees such as BSA do obtain measures of union recognition but these are likely to be more error-prone than individuals' reports of their own membership and of managers' reports of union recognition. This is indicated by the percentage of employees responding 'don't know' to the recognition question in BSA and the percentage who equivocate when asked whether they are sure of their answer. Conversely, however, personnel managers' estimates of the union membership status of their employees is likely to be less accurate than employees' own accounts. Evidence indicates that WERS managers tend to underestimate union density (Kersley et al., 2006: 111).

${ }^{16}$ The upward biases in union wage premium estimates associated with aggregate data relative to micro-data were well-known from H. Gregg Lewis's (1983) studies for the USA and were also apparent from the much lower estimate Stewart (1983) achieved with his analysis of the 1975 National Training Survey when compared with other UK studies which had used aggregate data.
} 
in the union wage premium in Britain to the demise of the closed shop over the period. $^{17}$

Multi-unionism was a big deal back in WIRS80 since 44 percent of workplaces recognising unions had more than one. Theoretically, it isn't clear a priori whether multiple-unionism, per se, is a proxy for union bargaining strength. As Blanchflower noted (1984: 320): 'On the one hand a pluralism of unions may strengthen the power of management who are able to play one union off against another. On the other hand, however, a plurality of unions may reinforce their overall bargaining power'. The latter appears particularly likely where multiple unions bargain jointly. Using WIRS84 Machin et al. (1993) found a union wage mark up associated with separate bargaining rather than multiple unionism per se, a finding consistent with Horn and Wolinsky's (1998) proposition that when a union represents only a section of the workforce it tends to ignore its bargaining externalities on other employees such as possible job loss associated with higher wages, and this is accentuated if unions bargain separately rather than jointly. Since then multi-unionism has declined (Millward et al., 2000), and those pockets that do exist may be workplaces where unionisation was particularly strong. Perhaps not surprisingly, then, analyses using WERS98 (Forth and Millward, 2002b; Booth and Bryan, 2004) found a wage premium associated with multiple unionism, though in Booth and Bryan's case it was confined to manual workers.

A recent preoccupation of analysts has been whether or not there is still a union wage premium in Britain. This seems implausible, not least because one would expect workers to obtain some tangible benefit from membership to induce them to join. However, there is some evidence of a decline in the premium. Using WERS98 Forth and Millward (2002b) found that the union premium was confined to employees in workplaces with high bargaining coverage or multiple unions. The absence of a general union premium is confirmed in analyses using other data sets such as British Social Attitudes: Bryson (2007) finds a premium of 5-7 percent in 1998 disappears by 2005 when running analyses that are identical in specification. Nevertheless, it is unclear from these studies whether this is a cyclical or secular phenomenon (Blanchflower and Bryson, 2003). ${ }^{18}$

\footnotetext{
${ }^{17}$ The other reason Stewart cites for the decline in the union wage premium was unions' inability to establish differentials in new workplaces.

${ }^{18}$ Another reason for exercising caution when drawing inferences about trends in the union wage premium is that estimates based on the first three surveys in the WERS series relied on workplace data, whilst estimates based on the later surveys are able to use data on individual employees. The two approaches may yield different estimates if the average premium varies by size of workplace. In addition, the estimation techniques used in earlier papers tend to generate higher estimates than the techniques currently in vogue. So, for instance, Booth and Bryan (2004) and Bryson (2006) find that the non-significant membership premium result is due to the use of IV and PSM estimation, respectively. OLS estimates presented in those papers are significant and much higher. The latest estimates from the Labour Force Survey for 2004 and 2005 indicate a union membership wage premium of 12 percent (controls are age, its square, male, 6 schooling dummies, 4 race dummies, 22 region of work dummies and 11 industry dummies.
} 
Since 1998 WERS has incorporated linked employee data, as noted earlier, which includes banded weekly earnings and continuous hours data permitting analyses of both workplace-level and individual-level union wage premia. These linked data also allow analysts to distinguish more clearly between the effects of union membership, bargaining coverage, and background individual and workplace characteristics. This is important since the premium is essentially a product of bargaining rather than membership. Membership provides the bedrock to give unions just cause to bargain, and it provides a source of power. But in Britain there is no necessary reason to expect that a wage premium will be attached to membership, other than the fact that recognition and membership are positively correlated. This point is often overlooked by those relying on household and individual surveys that often rely on membership as the indicator of unionisation simply because they lack true measures of bargaining activity. The dangers in doing so are illustrated by Blanchflower and Bryson (2004) whose analyses of WERS98 showed that estimates of the union membership wage premium based on employee-only data were upwardly biased because some of the positive wage effect attributed to membership was actually due to members being employed at better-paying workplaces.

One of the puzzles in the existing union wage premium literature is the apparent union membership wage premium even among workers covered by collective bargaining (Hildreth, 2000). The linked employer-employee data in WERS98 provided an opportunity to test whether this apparent premium was, in fact, due to unobserved differences between the workplaces employing members and nonmembers. Using linked employer-employee data from WERS98 Blanchflower and Bryson (2004) and Bryson (2006) show that the union membership premium falls dramatically among covered workers having controlled for observable workplace heterogeneity. Using a slightly different subset of the WERS98 data and controlling for unobservable workplace-level influences on wages by exploiting the within-workplace variation in wages Booth and Bryan (2004) find no significant union membership wage premium among covered workers, suggesting that the 'puzzle' has been solved, together with the seeming paradox of free-riders refusing to avail themselves of this benefit.

Multiple observations of employees within the same workplace also permit analyses of spillover effects of collective bargaining and union membership on uncovered workers and non-members. These effects prove to be fairly important. Using WERS98 Forth and Millward (2002b) found no general mark-up for employees covered by collective bargaining. However, there was evidence of a spillover effect from covered to uncovered workers in unionised establishments which suggests the presence of a small workplace-level wage premium of around $4 \%$ associated with the presence of recognised unions. ${ }^{19}$ Larger premia of around

\footnotetext{
19 This could be explained by employers reaching workplace-wide pay agreements, i.e. not discriminating between covered and uncovered workers. Consistent with this is Forth and Millward's (2002d) finding that most workplaces have a single settlement figure for all workers.
} 
$10 \%$, however, were confined to workers in workplaces with high bargaining coverage or multiple unions. Using WERS98, Belfield and Heywood (2001) also found the threat of unionisation was associated with higher wages for employees in the non-union sector. ${ }^{20}$

In another WERS98 paper Bryson, Forth and Kirby (2005a) find a union wage premium which is confined to what they define as 'high involvement management' (HIM) workplaces. Although these HIM practices are associated with higher labour productivity as well they do not affect the financial performance of union workplaces. These findings are consistent with concession wage bargaining (as opposed to 'mutual gains') or simply the hiking of wages in recognition of employees' increased labour productivity in the presence of HIM work practices. A further possibility suggested by Forth and Millward's (2004) WERS98 analysis identifying a wage premium associated with HIM workplaces is that unionization and HIM may be jointly determined, perhaps indicating that HIM workplaces tend to be high-wage workplaces where employers will value worker voice such as that offered by unions.

\section{Pay settlements}

It is worth recalling that, as well as furthering our understanding of pay levels, there is a strong WIRS tradition identifying factors associated with the size of pay settlements. WIRS is a useful source of information on this issue given its representative nature and the general lack of information on pay settlements in the economy more generally. However, its impact in policy discussions is limited given the gap between data collection and data analysis, such that policy analysts often resort to other data. ${ }^{21}$

The actual list of influences on pay settlements contained in WIRS would have been anathema to most economists at the time since manager's responses indicated that, quite unlike in the neoclassical economist's world, employers can be price-makers when it comes to setting wages, not just the 'takers' of prices for labour set by laws of supply and demand to which they are passive respondents. This is a standard observation for IR academics, but was far more controversial for labour economists grappling with early WIRS data, a point nicely illustrated

\footnotetext{
20 This effect did not reduce wage dispersion within non-union workplaces however, since the effect was no more pronounced for lower-paid than higher-paid employees.

21 The best known source is perhaps the CBI's Pay Databank. For examples of analyses using these data see, for example, Brown et al. (2004). However, these data are confined to CBI members and have traditionally focused on manufacturing settlements. The Databank was suspended in 2003 and is unlikely to resume. Other valuable sources include databases maintained by Incomes Data Services, Industrial Relations Services and the Labour Research Department. For more details see http://www.cipd.co.uk/subjects/pay/general/paysettle.htm.
} 
by Blanchflower and Oswald (1988a) in their paper on the role of firm-specific factors in pay determination.

Using WIRS84 Millward and Stevens (1986: 246-7) found that 'in general terms, the influences upon the pay settlements that were jointly regulated were not very different from those that were unilaterally determined by managers...the considerations taken into account in determining the pay of unionised workers applied also to unorganised workers. The difference lay not in the considerations, but in who considered them and how the decision was taken as to what weight should be attached to each'. There was one exception: merit and performance pay tended to be cited more often in non-union settings. ${ }^{22}$

Blanchflower and Oswald's papers (1998a, 1990a) developed the sourcebook analyses and supplemented them with multivariate analyses. They came to the same conclusion regarding influences over pay settlements in the union and nonunion sectors, namely that 'with the interesting exception of merit payments for individual performance, union and non-union pressures upon wage settlements are apparently similar' (Blanchflower and Oswald, 1988a: 367-268). Perhaps more importantly, however, Blanchflower and Oswald's (1988a; 1990a) papers and Blanchflower et al.'s (1990) paper raised severe doubts about the general applicability of the competitive model of pay determination by showing the importance of factors internal to the workplace in determining wage settlements and wage levels. Concluding their 1990 paper which identified the importance of factors such as workplace financial performance in determining the weekly earnings of 'typical' workers in WIRS84, the authors say (Blanchflower and Oswald, 1990a: 159:

"the broad conclusion from this paper is that the classical competitive model of the labour market does not provide an adequate explanation of wage determination in the United Kingdom. Instead, pay levels are shaped by an intricate blend of internal and external forces. For all but the unskilled non-union sector, a model based on the distinction between insiders and outsiders, where unions and bargaining play a central role, may offer the most appropriate framework. Even parts of the nonunionized sector of the economy exhibit signs of insider influence., 23

Blanchflower and Oswald (1994a, 1994b, 1995), extended this work further in their work on the wage curve. Interestingly, they first found evidence of their

\footnotetext{
${ }^{22}$ In WIRS80 very different questions about pay increases were asked of unionized and nonunionized workplaces precluding such comparisons (Daniel and Millward, 1983: 195-197).

${ }^{23}$ Blanchflower and Oswald (1994) went on to develop these ideas in their identification of the wage curve indicating a negative correlation between local wages and local unemployment, a relationship they first observed in WIRS80.
} 
curve using WIRS80 but did not find it in WIRS84. After a year or so puzzling over why that would be they realised that the higher levels of unemployment prevailing in 1984 might have resulted in a non-linearity in the wage curve and their subsequent book was born. Wage curves have now been found in over forty five countries (Blanchflower and Oswald, 2005).

Similar open-ended questions about influences on pay settlements were asked in WIRS90. WIRS84 had been conducted 'when the rate of inflation had fallen to a low level (Daniel and Millward, 1983: 246) whereas WIRS90 'was increasing from around 7 percent to nearly 10 percent after several years at around 5 percent' (Millward et al., 1992: 239). Yet in both surveys the cost of living was the most frequently cited consideration in pay settlements.

The WERS98 sourcebook devoted three and a half pages to pay determination (Cully et al., 1999: 106-109). Little wonder, then, that it did not report on the new set of pay settlements questions contained in the revamped questionnaire. The questions differed from those appearing in earlier surveys in two major respects. First, in previous surveys data had been collected for manual and non-manual workers separately. In WERS98, on the other hand, questions focused on the pay settlement for the core group of non-managerial employees at the workplace (what WERS terms the 'largest occupational group'). However, because twothirds of workplaces use identical arrangements for all occupational groups, analyses of pay settlements for core employees tend to be representative of workplaces as a whole (Millward et al., 2001). Second, the term 'pay settlements' was beginning to feel outmoded. As Forth and Millward (2002d: 3) note, 'pay settlements' was the 'pervasive but out-moded terminology of collective bargaining' for the process of periodic adjustment to pay levels. Thus the questionnaire referred to 'pay settlement or review' and 'pay settlement or award'. Millward et al.'s (2001) and Forth and Millward's (2002d) analyses of private sector pay setting using these richer data in WERS98 revealed a number of interesting features of the pay process. Inflation continued to play a key role in pay adjustments:

"despite inflation being at historically low levels, employers still review and adjust pay levels overwhelmingly on an annual basis. Settlements are clustered around the prevailing rate of inflation.... Employers very commonly cite the inflation rate as a major influence upon the size of settlements, but they also commonly say that settlements are the same for their employees as for others in the same industry. It is difficult to disentangle these two influences. However, we produce some empirical evidence that both are at work: private sector settlements were probably higher when background inflation was higher; and there is some evidence of employers following a 'going rate' (of increase) in their industry.” (Forth and Millward, 2002d: 25). 
Turning to the role of trade unions, as noted earlier, unions frequently had little or no involvement in pay settlements even when, ostensibly, they were subject to collective bargaining. Pay was reviewed more frequently where unions were present than in cases where management were free to choose the frequency of settlements. However, collectively bargained pay settlements were similar in size to settlements achieved in the absence of unions. This finding, in conjunction with the absence of an overall union wage premium in WERS98 (Forth and Millward, 2002b), suggests weakness in union bargaining power.

The analysis of pay settlements in the WERS04 sourcebooks was confined to an analysis by size of firm (Forth et al., 2006: 60). However, we have prepared new analyses of the 2004 data to complement that undertaken by Forth and Millward on WERS 1998. Many of the patterns noted by Forth and Millward remain (Table 2a). ${ }^{24}$ First, in unionised workplaces, pay remains more likely to be reviewed on an annual basis. It then seems likely that the process of pay review is more regular in unionised workplaces than in non-union establishments, although one cannot say this for certain since those reviews taking place more than once a year in non-union sites may nonetheless have a regular cycle (e.g. 6-monthly). Second, unionised settlements are more likely to be influenced by changes in the cost of living than non-union settlements, and are less likely to be influenced by workplace or organisation performance. Third, and in keeping with Blanchflower and Oswald's earlier analysis (Table 2b), pay increases awarded in unionised workplaces are more likely to follow the going rate for similar workers in the same industry or locality. Fourth, substantial minorities of pay settlements in unionised workplaces are apparently concluded without the direct involvement of union representatives or full-time officials. The involvement of employers' associations is extremely uncommon and has, apparently, become less prevalent since 1998.

\section{Variable pay}

Variable pay has been a central issue in WIRS since the outset. This is not surprising. IR academics had been studying the role of piece-rates and paymentsby-results in manufacturing for many years and their links with industrial unrest were a cause for concern to the Donovan Commission. Today, variable pay is often viewed as the antithesis of the 'standard' or 'common' rate-for-the-job pay determination principle underpinning union wage setting (Marsden, 2004). The idea, attractive to some, is that pay should match worker performance, not only because this might more fairly reflect employees' just deserts, but also because the incentive effects of the link can bring their own benefits in terms of greater worker motivation and loyalty, higher effort and thus productivity and thus, ultimately, improved financial performance.

\footnotetext{
${ }^{24}$ It is not possible to repeat Forth and Millward's analysis of the relative size of pay settlements in unionized and non-unionized settlements as data on settlement size was not collected in 2004.
} 
As sourcebook analysts readily admit:

"Systems of payment and reward are among the most complex phenomena that managers and researchers have to deal with. The WIRS series has never attempted to capture their complexity and instead has settled for small groups of questions about specific payment practices” (Millward et al., 2000: 211-212).

For this reason, WIRS' primary contribution to understanding variable payment systems has been in mapping their incidence over time, their correlates and, as noted above, their links to performance outcomes. The focus of the series has been on three types of system: payments by results (PBR), profit-related pay (PRP) and employee share ownership (ESOS).

Table 3 shows the incidence of PRP and ESOS. In interpreting trends one must bear in mind changes in question wording and question formatting which mean that figures are not always wholly comparable (see the footnotes to the table for details). However, some patterns are striking. First, PRP schemes grew dramatically in the 1980s. Speculation in the sourcebooks and early academic papers (eg. Blanchflower and Oswald, 1987) about the role of government tax incentives as a contributory factor was confirmed by panel analyses for the 1990s indicating tax incentives were an important reason for PRP adoption between 1990 and 1998 (Millward et al., 2000: 216). However, the percentage of trading sector workplaces with PRP schemes has been roughly static since then. This is, however, only half the story. Panel analyses for 1990-98 and 1998-2004 have indicated substantial switching in and out of PRP (Millward et al., 2000: 215-216; Bryson and Freeman, 2006b).

ESOS also grew in the 1980s, continuing a trend that had begun in the 1970s (Millward et al., 2000: 216). Again, tax treatment of the schemes may have played a role (Daniel and Millward, 1983: 210; Millward and Stevens, 1986: 259). As in the case of PRP, ESOS incidence has remained fairly static since 1990 though, again, the panel data show a considerable amount of switching in and out of share-ownership schemes (Millward et al., 2000: 216; Bryson and Freeman, 2006b). If one follows the WIRS sourcebooks in treating PRP and ESOS as schemes engendering financial participation by workers, then 57 percent of trading sector workplaces had such a scheme in 2004, a figure roughly comparable to that in 1990 (last row of Table 3). Yet some analysts continue to hold their breath in anticipation of an explosion in financial participation since this would seem to fit with trends towards greater reliance on employee initiative and the devolution of decision-making to teams and individuals.

PBR has always been treated rather differently from PRP and ESOS in the WIRS sourcebooks. PBR first appeared in Daniel and Millward (1983: 200) under the heading 'systems of payment and control'. It was reported on alongside methods for controlling time keeping and payments while sick and was treated as one of 
the 'methods of bureaucratic control' (op.cit.) targeted at manual workers, thus reflecting 'strong class divisions' (op.cit.) in British workplaces. In the Donovan tradition, PBR was treated as part of the problem of shop floor bargaining and a cause of industrial strife (Daniel and Millward, 1983: 292). As Blanchflower and Cubbin (1986: 26) note, PBR has traditionally been included in analyses of strike propensities since, though the need for regular adjustments to pay, it increases opportunities for disagreement.

Daniel and Millward (1983: 205) went on to argue:

"Traditionally the purpose of PBR systems of pay has been to encourage workers to increase effort and output....In practice....there has been a tendency for PBR to become more an instrument of management control designed to ensure consistency of output.”

By WERS98, however, PBR was more common among non-manual than manual workers (Millward et al., 2000: 213) and was categorised as a form of incentive payment rather than as a method of control, an approach also adopted in the WERS04 sourcebook (Kersley et al., 2006: 190-191).

It is harder to track the changing incidence of PBR than it is PRP and ESOS due to alterations in wording and format. ${ }^{25}$ However, PBR was clearly increasing in the 1970s pre-WIRS due to incomes policies (Daniel and Millward, 1983: 207208). Workplace-level incidence of PBR is not available for 1980 and $1984{ }^{26}$ WIRS90 enquired about PBR - calculated on an individual, group or establishment or organization basis - and merit pay, the latter being related to the subjective assessment of performance by a supervisor or manager. Millward et al. (1992: 260) report 52 percent of workplaces having at least one such scheme covering some employees.

A revamping of the questions in 1998 makes tracking changes in the incidence of PRP over the 1990s difficult but Millward et al.'s (2000: 213) comparisons of cross-sectional and panel data suggested little change, or a possible small reduction in incidence. ${ }^{27}$ WERS04 reverts to question wording similar to that used in WIRS90. Using this measure, 53 percent of workplaces with 25 or more employees in the trading sector had either PBR or merit pay in 2004, compared to

\footnotetext{
${ }^{25}$ For details of these changes see Millward et al., 2000: 212-213 and footnotes 20, 21 and 22 and Kersley et al., 2006: 190-191 and footnotes 10 and 11.

${ }^{26}$ The only mention of PBR (and indeed PRP) in the WIRS84 sourcebook is a reference to their presence in the data set in footnote 16 of the concluding chapter.

27 The 1990 incentive pay figures cited in Millward et al. (2000: 212-213) are very different from those cited by Millward et al. (1992: 260) for 1990, a matter that requires further investigation.
} 
52 percent in $1990 .^{28}$ However, using identical PBR measures in the 1998-2004 panel, it is apparent that PBR rose among private sector workplaces with adopters vastly outnumbering those dropping their PBR schemes (Bryson and Freeman, 2006b). Thus it appears that there has been a substantial increase in the use of PBR since 1998 though, on measures that are only roughly comparable, there has been little change in PBR and merit pay incidence since 1990.

Individual incentive payments, profit-related pay and share schemes have continued to interest IR academics and labour economists because they can affect productivity and performance, pay levels, pay settlements and wage variation within and across workplaces. In fact, most analyses have focused on the links between variable pay and performance. Numerous WIRS studies testify to the complex links between such payments and performance (Blanchflower and Oswald, 1988b using WIRS84 is one of the earliest studies; for an analysis using WERS04 and a review of this largely WIRS-based literature see Bryson and Freeman, 2006b). On balance, one might conclude that there are positive though modest productivity returns to variable pay systems, that any benefits differ markedly by type of variable pay scheme, and that - as IR academics have pointed out on a number of occasions - the way in which schemes are implemented and the criteria used to measure and reward performance are critical, sometimes creating adverse effects that would have been avoided in the absence of the scheme.

Far less attention has been devoted to the links between these variable pay methods and pay outcomes. Though it is not the focus of their paper, in their analysis of WERS98 Belfield and Heywood (2001) find incentive pay increases wage dispersion (coefficient of variation) at workplace level whereas PRP and ESOS are not significant. There is no recent WIRS research assessing the effect of variable payments on pay levels though early WIRS studies found PBR was associated with higher pay for manual workers.

\section{Climate of employment relations}

As Marginson (1998: 378) notes 'respondents are not only informants, they are also actors within the workplace...relating events and practices of which they are a part'. Given the 'contested' nature of IR reliance on a single role-holder, such as workplace HR managers, may lead to a partial or biased picture of the nature of IR in the workplace. With multiple respondents often asked similar or identical questions about their perceptions of IR, WIRS has been able to establish the degree of 'dissonance' between respondents within the same workplace and has helped to explain reasons for the differences. This is nowhere more apparent than

\footnotetext{
${ }^{28}$ The measures are not directly comparable since WIRS90 asked 8 occupational groups whether they had such payments where the establishment had 5 or more employees in that occupational group WERS04 first asks if any employees at the establishment get PBR or merit pay.
} 
in the case of perceptions of the climate of employment relations in the workplace.

In the late 1970s and early 1980s, the IR climate was assessed in terms of the number and duration of strikes. Relating how the PEP 1975/76 workplace survey was conducted Daniel (1976) cites the 3 day week as a reason for disruption to survey schedule. The survey found that over half ( 57 percent) of manufacturing plants rating IR as "good" cited 'lack of strikes/disputes' as a reason for their rating (1976: 9), by far the most heavily cited reason, confirming the centrality of industrial disputes in managers' day-to-day thinking about IR. As Daniel notes (1976: 8): "managers tend to define good industrial relations as being the absence of any disruption to working and the lack of any challenge to their authority". This was the case in spite of the fact that, at the time of the survey strikes were at their lowest since 1968 (1976: 8-9).

WIRS80 made a number of contributions to discussions about industrial conflict in Britain. First, it gave a more accurate picture of the incidence of industrial action than other sources. Just as the Warwick Workplace Survey had identified strikes of short duration and those in smaller workplaces were under-recorded (Brown, 1981:97-101) so WIRS80 provided information on the incidence of industrial action short of a strike where official statistics were either absent or patchy (Daniel and Millward, 1983: 291-3). Furthermore, as IR scholars might have anticipated, Daniel and Millward (1983) found managers and worker representatives in WIRS80 disagreed about the occurrence of industrial action, a finding replicated in subsequent surveys.

Second, it supplemented information on the incidence of strike action with other information about conflict at work such as claims to industrial (employment) tribunals and perceptions of the 'climate' of IR at the workplace. Management perceptions of 'climate' indicate an improvement in IR since 1990 but, perhaps surprisingly, relations remain poorer than they were in the early 1980s (Table 4). The table also shows that, whereas managerial perceptions of climate were poorer in union workplaces than in non-union workplaces in 1980-1990, the gap had disappeared by 1998.

In addition to the single-item climate indicator available in WIRS since the outset, WIRS includes items such as sanctions against employees (formal written warnings, suspensions of employees, deductions from pay, internal transfers for disciplinary reasons), and days lost through sickness and absence. These have proven particularly valuable in obtaining a comprehensive picture of employment relations and workplace conflict following the virtual disappearance of industrial action by 2004 (Kersley et al., 2006: chapter 8). The single-item climate variable is correlated with these alternative measures in the way one would imagine (Kersley et al., 2006: 278-279). Other measures of climate are available in the Survey of Employees and have been used by some analysts to construct multi- 
item composite indexes of climate in the absence of validated scales in WERS (Guest et al., 1999; Ramsay et al., 2000).

Third, WIRS showed different actors had very different perceptions of the climate of IR at the workplace. Data for worker representatives matched to that of managers showed that reps have a poorer perception of the industrial relations climate than their managerial counterparts (Daniel and Millward, 1983: 254-256). This finding has been replicated over the course of WIRS. The advent of linked employer-employee data in 1998 meant that analysts were able to assess managers' perceptions of IR climate alongside those of employees in the same workplace. Comparisons revealed that managers tended to view climate more positively than their employees in the population with 25 employees or more (Cully et al., 1999: 283) and the population with 10 or more employees (Bryson, 2005). Similar findings have been reported for 2004 (Kersley et al., 2006: 278). What's more, over the period 1998-2004, there has been an improvement in managers' perceptions of climate that is not apparent among employees (Kersley et al., 2006: 277-278).

Fourth, WIRS permitted analysts to investigate workplace-level correlates of IR climate and industrial conflict. Blanchflower and Cubbin's (1986) paper using WIRS80 was the first to use micro data to assess propensities for various types of industrial action. Their coverage of the non-manufacturing sector was also novel. Their findings from multivariate analyses broadly confirmed results from the cross-tabular analyses undertaken by Daniel and Millward (1983). Using WERS98 Knight and Latreille (2000) looked at the correlates of individual conflict as measured by workplace variability in disciplinary action, dismissals and tribunal applications. They showed that both workplace and workforce characteristics explained much of the variance. Analyses of WERS98 and WERS04 have also shown that correlates of positive perceptions of climate differed markedly across managerial respondents and employees within the same workplace (Bryson, 2005; Kersley et al., 2006: 279-286).

\section{Unions and employment growth}

Finally, we turn to the literature on the effect of unions on workplace-level employment in Britain to illustrate two things. First, although changes in workplace employment have featured in the WIRS sourcebooks - notably when Millward and Stevens (1986: 11-13) reported a 'preponderance of establishments with declining employment numbers' over the recession period $1980-84^{29}$ - the analyses of this issue have largely occurred in academic papers. ${ }^{30}$ This literature is dominated by numbers from WIRS. Second, it illustrates the way in which

\footnotetext{
${ }^{29}$ Also see Millward et al., 2000:26-27.

${ }^{30}$ WIRS sourcebooks have focused more on the ways in which workplaces make workforce reductions. For example, Millward et al., 1992: 320-326; Cully et al., 1999: 79-80.
} 
WIRS can help us understand IR not simply through the 'mapping' of the terrain but by trying to understand the relationship between key variables in the data. What is striking about this particular illustration is that this relationship between unionization and establishment employment change has remained roughly constant over the years.

The WIRS literature on unions' employment effects has focused on changes in workplace employment levels. Early studies used retrospective data from managers on employment levels in earlier years to estimate union effects on employment change. More recent studies have begun to use the WIRS panel data, thus obtaining more accurate information. Studies tend to find that the average effect of union recognition is to lower employment growth by 2.5-4 per cent per annum relative to non-union workplaces, ceteris paribus (Blanchflower, Millward and Oswald, 1991; Machin and Wadhwani, 1991; Booth and McCullogh, 1999; Bryson, 2004; Addison and Belfield, 2004). Similar findings emerge from other countries (see Bryson, 2004 for a review). This has led some analysts to refer to the employment effect of unions as the 'one constant' in studies of unions' economic effects (Addison and Belfield, 2004).

However, the evidence is not all one-way. The effect is not apparent always and everywhere. There is conflicting evidence on the union effect on employment growth in the late 1970s: Machin and Wadhwani (1991) identify a positive effect whereas Blanchflower et al. (1991) find a negative effect. Furthermore, some studies find union effects differ according to the nature of unionisation and the conditions facing the firm. For instance, negative employment growth effects in the 1990s were more pronounced where bargaining coverage is high (Bryson, 2004) whereas the effect is ameliorated when unions bargain over employment and wages (2004: 494-495). Most of these studies focus on the private sector. However, Addison and Belfield (2004) find negative employment growth effects of union recognition in the public sector similar to those for the private sector. In addition, they find evidence for the public sector that changes in workplace-level union recognition affect employment growth, with new recognitions reducing employment growth and union de-recognition increasing employment growth (Addison and Belfield, 2004). These union switches do not affect employment growth in the private sector.

Interpreting these union effects is quite a different matter. Some question whether the link is causal (Metcalf, 2005: 100). It is only recently that WIRS analysts have shown that this union effect is not solely attributable to a slower rate of employment growth, but is also attributable, at least in part, to a greater propensity for unionized workplaces to undertake within-workplace job cuts (Bryson and White, 2006). It remains to be seen whether analyses of the WERS98-04 panel will reveal the same 3 percent reduction in employment growth associated with unionization. 


\section{Concluding Remarks}

This paper has sought to illustrate how WIRS marked a big departure in our understanding of IR in Britain. In particular, the first two surveys, WIRS80 and WIRS84, when taken together, fostered a new understanding of IR in Britain and how it was changing. It was 'new' in the sense that the IR community had little else to go on that was nationally representative of all broad sectors of the economy. It was also clear that the choice of the workplace as the visor through which we came to know IR was the appropriate level of analysis for many of the institutions and practices that were of greatest interest. Simply establishing this way of conceiving IR was a considerable achievement.

It is unsurprising, therefore, that these early surveys began to change the way we thought about IR in Britain. One view is that a large number of the first order questions about the nature of collective IR in Britain were answered in those early surveys undertaken in 1980 and 1984. Contrary to popular perception, these early studies painted a reasonably clear picture of the non-union sector in Britain. Diminishing returns may well have set in after the first two surveys. The contrary point of view is that revisions to the questionnaires and the addition of new survey instruments means WIRS is better able to 'map' IR. Perhaps one of the issues facing WIRS in subsequent years, identified by Millward (2001), is the difficulty surveys have in categorizing the non-union sector which, by its nature, is less rule-bound than the union sector. It has proven difficult to construct proxies for 'slippery' concepts that are key in non-union settings - and, indeed, to the HRM practices that are so common in the union sector. The 'de-institutionalisation' of IR means it has also become more difficult to construct proxies for union activity.

Five surveys, nine sourcebooks ${ }^{31}$ and numerous journal articles down the line ${ }^{32}$, we are used to seeing British IR through the lens of the workplace. This is a remarkable achievement in many ways, as the foregoing discussion has illustrated, not least because an authoritative picture of IR and IR change is not available in most other countries around the world - including the USA. The United States may have produced the most heavily cited IR book ever (Freeman and Medoff, 1984) but it did so without representative workplace-level data. Indeed, in reviewing Kersley et al. (2006) Freeman described WIRS as 'the gold standard survey of personnel and labour relations' going on to say:

"If only the US was smart enough to imitate this masterful survey”.

\footnotetext{
${ }^{31}$ Daniel and Millward (1983); Millward and Stevens (1986); Daniel (1987); Millward et al. (1992); Millward (1994); Cully et al. (1999); Millward et al. (2000); Kersley et al. (2006); Forth et al. (2006)

${ }^{32}$ We estimate there are around 400-450 WIRS publications. Roughly 165 of these are articles in refereed journals and 15 are books.
} 
Table 1: Percentage of workplaces with 25+ employees recognizing unions, 1980 $-2004$

\begin{tabular}{|l|c|c|c|c|c|}
\hline & 1980 & 1984 & 1990 & 1998 & 2004 \\
\hline Manufacturing & 65 & 56 & 44 & 28 & 37 \\
\hline Private Services & 41 & 44 & 36 & 23 & 20 \\
\hline Public Sector & 94 & 99 & 87 & 87 & 88 \\
\hline All & 64 & 66 & 53 & 42 & 39 \\
\hline
\end{tabular}

Sources: Millward et al., 2000; Willman and Bryson (2006) based on WERS. Note that 1998 figures based on new weights explaining difference in 1998 private manufacturing figure compared with Millward et al. 2000. 
Table 2a: Characteristics of the most recent pay settlement for core employees in private sector workplaces, 1998 and 2004

\begin{tabular}{|c|c|c|c|c|}
\hline & \multicolumn{2}{|c|}{1998} & \multicolumn{2}{|c|}{2004} \\
\hline & $\begin{array}{l}\text { No union } \\
\text { recognized }\end{array}$ & $\begin{array}{l}\text { Union } \\
\text { recognized }\end{array}$ & $\begin{array}{l}\text { No union } \\
\text { recognized }\end{array}$ & $\begin{array}{l}\text { Union } \\
\text { recognized }\end{array}$ \\
\hline \multicolumn{5}{|l|}{ Frequency of pay review: } \\
\hline More than once a year & 7 & 5 & 9 & 2 \\
\hline Annually & 85 & 91 & 86 & 95 \\
\hline Less than once a year & 8 & 4 & 4 & 2 \\
\hline \multicolumn{5}{|l|}{ Factors affecting most recent settlement: } \\
\hline Changes in cost of living & 71 & 80 & 55 & 76 \\
\hline Ability to recruit/retain employees & - & - & 49 & 36 \\
\hline Organization or workplace performance & 75 & 65 & - & - \\
\hline $\begin{array}{l}\text { Financial performance of organization or } \\
\text { workplace }\end{array}$ & - & - & 69 & 64 \\
\hline $\begin{array}{l}\text { Productivity levels within organization } \\
\text { or workplace }\end{array}$ & - & - & 46 & 39 \\
\hline Industrial action threatened or taken & 2 & 12 & $<1$ & 4 \\
\hline Risk of redundancies & 11 & 22 & - & - \\
\hline \multicolumn{5}{|l|}{ Change at last review: } \\
\hline Increase & 95 & 97 & 87 & 93 \\
\hline No change & 5 & 2 & 13 & 7 \\
\hline Decrease & $<1$ & 1 & $<1$ & $<1$ \\
\hline \multicolumn{5}{|l|}{$\begin{array}{l}\text { Where pay increase, settlement same as } \\
\text { that for: }\end{array}$} \\
\hline Managers at this workplace & 66 & 76 & 66 & 66 \\
\hline Other non-managerials & 85 & 88 & 82 & 81 \\
\hline Similar workers in same industry/sector & 67 & 79 & 66 & 76 \\
\hline Similar workers in same locality & 62 & 79 & 64 & 67 \\
\hline \multicolumn{5}{|l|}{ Where pay increase, who was involved: } \\
\hline Union representatives & 2 & 60 & 1 & 57 \\
\hline
\end{tabular}

Base: private sector establishments with 10 or more employees 
Table 2b. Factors influencing the level of private sector pay settlements in the most recent pay settlement

\begin{tabular}{|l|c|c|c|c|}
\hline & \multicolumn{2}{|c|}{ Manuals } & \multicolumn{2}{c|}{ Non-manuals } \\
\hline & Union & $\begin{array}{c}\text { Non- } \\
\text { union }\end{array}$ & Union & $\begin{array}{c}\text { Non- } \\
\text { union }\end{array}$ \\
\hline All establishment could afford & 11 & 5 & 9 & 7 \\
\hline Increasing cost of living & 36 & 29 & 37 & 32 \\
\hline Going rate in industry & 15 & 23 & 13 & 19 \\
\hline Merit/individual performance & 4 & 20 & 5 & 33 \\
\hline Published norms & 3 & 2 & 3 & 4 \\
\hline Internal pay structure & 2 & 3 & 6 & 15 \\
\hline External pay structure & 15 & 15 & 9 & 11 \\
\hline Government regulation & 6 & 3 & 10 & 2 \\
\hline Strikes & 1 & 0 & 0 & 0 \\
\hline Profitability/productivity & 34 & 35 & 37 & 38 \\
\hline Economic climate & 9 & 2 & 13 & 3 \\
\hline Other & 13 & 7 & 15 & 6 \\
\hline Not answered & 8 & 3 & 11 & 1 \\
\hline N & 488 & 613 & 356 & 904 \\
\hline
\end{tabular}

Source: Blanchflower and Oswald (1988), Table 2 
Table 3: Incidence of profit-related pay and share-ownership schemes among trading sector workplaces with 25+ employees, 1980 - 2004

\begin{tabular}{|l|c|c|c|c|c|}
\hline & 1980 & 1984 & 1990 & 1998 & 2004 \\
\hline Profit-related pay & NA & 19 & 44 & 46 & 44 \\
\hline $\begin{array}{l}\text { Share-ownership } \\
\text { schemes }\end{array}$ & 13 & 22 & 30 & 24 & 30 \\
\hline $\begin{array}{l}\text { Any profit-related } \\
\text { pay or share- } \\
\text { ownership scheme }\end{array}$ & NA & 30 & 54 & 50 & 57 \\
\hline
\end{tabular}

Notes:

(1) Figures through to 1998 from Millward et al. 2000: 214-217. Own calculations for 2004.

(2) Trading sector includes the small number of publicly owned commercial companies, but their exclusion makes little difference to the figures.

(3) Wording changes mean PRP and ESOS schemes may have been under-recorded in 1998. See Millward et al. 2000: 214-216 and footnote 24 and Kersley et al., 2006: 191-193 
Table 4: Managerial perceptions of the IR climate among workplaces with 25+ employees, 1980 - 2004

\begin{tabular}{|l|c|c|c|c|c|}
\hline & 1980 & 1984 & 1990 & 1998 & 2004 \\
\hline Panel A: Whole economy & 49 & 38 & 32 & 39 & 39 \\
\hline Very good & 49 & 57 & 61 & 51 & 53 \\
\hline Good & 45 & 34 & 28 & 40 & 37 \\
\hline Panel B: Unionized workplaces & 53 & 62 & 63 & 50 & 55 \\
\hline Very good & 56 & 48 & 37 & 39 & 41 \\
\hline Good & 41 & 48 & 59 & 52 & 53 \\
\hline Panel C: Non-unionized workplaces &
\end{tabular}

Note: the categories 'neither good nor poor', 'poor' and 'very poor' account for the remainder 


\section{References}

Addison, J. T. and Belfield, C. R. (2004), 'Unions and employment growth: the one constant?’, Industrial Relations, Vol. 43, No. 2, 305-323

Belfield, C. R. and Heywood, J. S. (2001), 'Unionization and the pattern of nonunion wages: evidence for the UK', Oxford Bulletin of Economics and Statistics, 63, 5: 577-598

Blackburn, R. (2005), 'Researching the employment relationship in small firms: what are the contributions from the employment relations and small business literatures?', in S. Marlow, D. Patton and M. Ram (eds.), Managing Labour in Small Firms, London: Routledge.

Blanchflower, D.G. (1984), 'Union relative wage effects: a cross-section analysis using establishment data’, British Journal of Industrial Relations, 311-332

Blanchflower, D.G. (1986), 'What effect do unions have on relative wages in Great Britain?’, British Journal of Industrial Relations, 24, 2: 195-204

Blanchflower, D.G. (2007), 'A cross-country study of union membership’, $\underline{\text { British }}$ Journal of Industrial Relations, March.

Blanchflower, D.G. and Bryson, A. (2003), 'Changes over time in union relative wage effects in the UK and the US Revisited', chapter 7 in International Handbook of Trade Unions, John T. Addison and Claus Schnabel (eds.), Edward Elgar, Cheltenham England and Northampton Mass., USA

Blanchflower, D.G. and Bryson, A. (2004), 'Union relative wage effects in the United States and the United Kingdom', Proceedings of the $56^{\text {th }}$ Annual Meeting of the Industrial Relations Research Association, 133-140

Blanchflower, D.G. and Cubbin, J. (1986), 'Strike propensities at the British workplace’, Oxford Bulletin of Economics and Statistics, 48, 1: 19-39

Blanchflower, D.G. and Millward, N. (1988), 'Trade unions and employment change’, European Economic Review, 32, 717-726.

Blanchflower, D.G., N. Millward and Oswald, A.J. (1991), 'Unionism and employment behaviour’, Economic Journal, 101, Issue 407, 815-834.

Blanchflower, D. G. and Oswald, A. J. (1987), 'Profit sharing - can it work?', Oxford Economic Papers, 39, 1: 1-19 
Blanchflower, D.G. and Oswald, A.J. (1988a), 'Internal and external influences upon pay settlements’, British Journal of Industrial Relations, 26, 3: 363-370

Blanchflower, D.G. and Oswald, A.J. (1988b), 'Profit-related pay: prose discovered?’, Economic Journal, 98, 392: 720-730

Blanchflower, D. G. and Oswald, A. J. (1990a), 'The determinants of white-collar pay’, Oxford Economic Papers, 42, 2: 356-378

Blanchflower, D.G. and Oswald, A.J. (1990b), ‘The wage curve', Scandinavian Journal of Economics, 92, pp. 215-235. Reprinted in Unemployment and wage determination in Europe, edited by B. Holmlund and K.G. Lofgren, Basil Blackwell.

Blanchflower, D.G. and Oswald, A.J. (1995), 'An introduction to the wage curve’, Journal of Economic Perspectives, Summer, pp. 153-167.

Blanchflower, D.G. and Oswald, A.J. (1994a), The Wage Curve, MIT Press: Cambridge, Mass.

Blanchflower, D.G. and Oswald, A.J. (1994b), 'Estimating a wage curve for Britain’, 1973-1990', Economic Journal, September, 1994, pp.1025-1043.

Blanchflower, D.G. and Oswald, A.J. (2005), 'The wage curve reloaded,' NBER Working Paper 11338

Blanchflower, D.G., Oswald, A.J. and Garrett, M. (1990), 'Insider power in wage determination', Economica, 57, 226: 143-170

Blanden, J., Machin, S. and Van Reenen, J. (2006), 'Have unions turned the corner? New evidence on recent trends in union recognition in UK firms', British Journal of Industrial Relations, 44: 2, 169-190

Booth, A. and Bryan, M. (2004), 'The union membership wage-premium puzzle: is there a free rider problem?,' Industrial and Labor Relations Review, 57: 402421

Booth, A.L. and A. McCullough (1999), 'Redundancy payments, unions and employment, The Manchester School, 67(3), 346-66.

Brown, D., Ingram, P. and Wadsworth, J. (2004), 'Pay settlements and nominal wage rigidity in Britain’, British Journal of Industrial Relations, 42, 3: 507-525

Brown, W. (1986), 'The Changing role of unions in the management of labour', British Journal of Industrial Relations, 24, 2: 161-168 
Brown, W., Deakin, S., Hudson M., Pratten, C. and Ryan, P. (1998), The individualisation of employment contracts in Britain, Department of Trade and Industry, Employment Relations Research Series Report No. 4, London

Brown, W. (ed.), (1981), The Changing Contours of British Industrial Relations, Basil Blackwell, Oxford.

Bryson, A. (2004), 'Unions and employment growth in british workplaces during the 1990s: a panel analysis', Scottish Journal of Political Economy, 51(4), 477506.

Bryson, A. (2005), 'Union effects on employee relations in Britain', Human Relations, 58, 9: 1111-1139

Bryson, A. (2006), 'The Size of the union membership wage premium in Britain's private sector', PSI mimeo

Bryson, A. (2007), 'New Labour, new unions?', Chapter 8, in A. Park, J. Curtice, K. Thomson, M. Phillips and M. Johnson (eds.), British Social Attitudes: the $23^{\text {rd }}$ Report - Perspectives on a Changing Society, London: Sage

Bryson, A., Forth, J. and Kirby, S. (2005a), 'High-performance practices, trade union representation and workplace performance in Britain', $\underline{\text { Scottish Journal of }}$ Political Economy, 53, 3: 451-491

Bryson, A. and Freeman, R. (2006a), 'Worker needs and voice in the US and the UK', NBER Working Paper No. 12310, Cambridge, Mass.

Bryson, A. and Freeman, R. (2006b), Doing the right thing? does fair share capitalism improve workplace performance?, mimeo

Bryson, A., Gomez, R. and Willman, P. (2004), 'The end of the affair? the decline in employers’ propensity to unionize', Chapter 8 in J. Kelly and P. Willman (eds.), Union Organization and Activity, Routledge, London, pp.129-149

Bryson, A., Gomez, R. and Kretschmer, T. (2005b), 'Catching a wave: the adoption of voice and high commitment workplace practices in Britain, 19841998', CEP Discussion Paper No.676, London School of Economics

Bryson, A. and White, M. (2006), 'Unions, within-workplace job cuts and job security guarantees’, Centre for Economic Performance Discussion Paper No. 733

Card, D., Lemieux, T. and Riddell, W. C. (2003), Unionization and wage inequality: a comparative study of the US, the UK and Canada, NBER Working Paper \#9473 
Cully, M. (1998), A survey in transition: the design of the 1998 Workplace Employee Relations Survey, London: Department of Trade and Industry

Cully, M. and Marginson, P. (1995), 'The Workplace Industrial Relations Surveys: Donovan and the burden of continuity', Warwick Papers in Industrial Relations, No. 55, Coventry: Industrial Relations Research Unit

Daniel, W.W. (1976), Wage Determination in Industry, Political and Economic Planning, Vol. XLII No. 563, June.

Daniel, W.W. (1987), Workplace Industrial Relations and Technical Change, London: Policy Studies Institute

Daniel, W.W. and Millward, N. (1983), Workplace Industrial Relations in Britain, London: Heinemann

Forth, J., Bewley, H. and Bryson, A. (2006), Small and Medium-Sized Enterprises: Findings from the 2004 Workplace Employment Relations Survey, London: Department of Trade and Industry

Forth, J. and Millward, N. (2002a), 'The determinants of pay levels and fringe benefit provision in Britain', NIESR Discussion Paper No. 171, London: National Institute of Economic and Social Research

Forth, J. and Millward, N. (2002b),. 'Union effects on pay levels in Britain'. Labour Economics, 9 (2002), 547-561

Forth, J. and Millward, N. (2002c),. The implications of complex survey samples for quantitative analysis in the field of employment relations: substantive findings. National Institute of Economic and Social Research, Mimeo.

Forth, J. and Millward, N. (2002d), 'Pay settlements in Britain', NIESR Discussion Paper No. 173, London: National Institute of Economic and Social Research

Forth, J. and Millward, N. (2004), 'High involvement management and pay in Britain,' Industrial Relations, 43, 1: 98-119.

Freeman, R.B. and Medoff, J. (1984), What Do Unions Do?, Basic Books, New York

Gall, G. (2004), 'Trade union recognition in Britain 1995-2002: turning a corner?’, Industrial Relations Journal, 35: 249-69

Gallie, D. (1994) "Methodological appendix", in J. Rubery and F. Wilkinson (eds) Employer Strategy and the Labour Market, Oxford: Oxford University Press. 
Godard, J. (2001), 'Beyond the high-performance paradigm? An analysis of variation in Canadian managerial perceptions of reform programme

effectiveness,' British Journal of Industrial Relations, 39, 1, pp. 25-52.

Godard, J. (2004), 'A critical assessment of the high-performance paradigm.' British Journal of Industrial Relations, 42, 2, pp. 25-52.

Government Social Survey (1968), Workplace Industrial Relations, HMSO: London

Guest, D. (1995), 'Human Resource Management, Trade Unions, and Industrial Relations.' in J. Storey, ed. Human Resource Management,London: Routledge, pp. 110-41.

Guest, D., Michie, J., Conway, N. and Sheehan, M. (1999), 'Partnership and Performance: an analysis using the 1998 Workplace Employment Relations Survey', paper presented at the BJIR/WERS98 Conference, Cumberland Lodge

Hildreth, A. K. G. (2000), 'Union wage differentials for covered members and non-members in Great Britain’, Journal of Labor Research, 21 (1), 133-147.

Horn, H. and Wolinsky, A. (1988), 'Worker substitutability and patterns of unionisation’, Economic Journal, 98, 484-7.

Kersley, B., Alpin, C., Forth, J., Bryson, A., Bewley, H., Dix, G. and Oxenbridge, S. (2006), Inside the Workplace: Findings from the 2004 Workplace Employment Relations Survey, London: Routledge.

Knight, K.G and Latrielle, P. (2000), 'Discipline, dismissals and complaints to employment tribunals’, British Journal of Industrial Relations, 38(4), 533-555.

Lewis, H.G. (1963), Unionism and Relative Wages in the United States, Chicago: University Press, Chicago, Illinois.

Lewis, H.G. (1983), 'Union relative wage effects: a survey of macro estimates', Journal of Labor Economics, 1, 1: 1-27.

McCarthy, W.E.J. (1967), 'The role of shop stewards in British industrial relations', in Royal Commission on Trade Unions and Employers' Associations Research Paper No. 1. London: HM Stationery Office.

McCarthy, W. (1994), 'Of hats and cattle: or, the limits of macro-survey research in industrial relations', Industrial Relations Journal, 25: 315-22.

Machin, S. (2000), 'Union decline in Britain,' British Journal of Industrial Relations, Vol. 38, No. 4 (December), pp. 631-45. 
Machin, S., Stewart, M. and Van Reenen, J. (1993), 'The economic effects of multiple unionism: evidence from the 1984 Workplace Industrial Relations Survey', Scandinavian Journal of Economics, 95, 3: 279-96.

Machin, S. and Wadhwani, S., 1991. 'The effects of unions on organisational change and employment', Economic Journal, 101, 835-854

Machin, S. and Wood, S. (2005), 'Human resource management as a substitute for trade unions in British workplaces', Industrial and Labor Relations Review, 58: 2, 201-218

Marginson, P. (1998), 'The survey tradition in British Industrial Relations Research: an assessment of the contribution of large-scale workplace and enterprise surveys', British Journal of Industrial Relations, 36: 3, 361-388

Marginson, P. and Wood, S. (2000), 'WERS98 Special Issue: Editors' introduction', British Journal of Industrial Relations, 38: 4, 489-496.

Marsden, D. (2004), 'Unions and procedural justice: an alternative to the 'common rule', in A. Verma and T.A.Kochan (eds.), Unions in the $21^{\text {st }}$ Century: An International Perspective, London: Palgrave Macmillan

Metcalf, D. (2005), 'Trade unions: resurgence or perdition? An economic analysis,' In S. Fernie and D. Metcalf (eds.), Trade Unions: Resurgence or Demise?, London: Routledge, pp.83-118

Millward, N. (1991) “Sampling establishments for social survey research”, $\underline{\text { The }}$ Statistician, 40: 145-152.

Millward, N. (1994), The New Industrial Relations?, London: Policy Studies Institute

Millward, N. (2001), 'Threats to the validity of international comparisons: units of analysis, the operationalisation of constructs and some analysis issues', paper to the International Conference on Organisational Design, Management Styles and Firm Performance, Bergamo, Italy, 22-23 June

Millward, N., Bryson, A. and Forth, J. (2000), All Change at Work? British Employment Relations 1980-1998 as portrayed by the Workplace Industrial Relations Survey series, London: Routledge

Millward, N., Forth, J. and Bryson, A. (2001), Who Calls the Tune at Work? The Impact of Unions on Jobs and Pay, Joseph Rowntree Foundation, York

Millward, N., Marginson, P. and Callus, R. (1998), 'Large-scale national surveys for mapping, monitoring and theory development'. In K. Whitfield and G. Strauss 
(eds.), Researching the World of Work: Strategies and Methods in Studying Industrial Relations, Ithaca, NY: ILR Press

Millward, N. and Stevens, M. (1986), British Workplace Industrial Relations 1980-1984, Aldershot: Gower

Millward, N., Stevens, M., Smart, D. and Hawes, W. R. (1992), Workplace Industrial Relations in Transition, Aldershot: Dartmouth

Parker, S. (1974), Workplace Industrial Relations 1972, OPCS/HMSO: London

Parker, S. (1975), Workplace Industrial Relations 1973, OPCS/HMSO: London

Purcell, J. (1993), 'The end of institutional industrial relations', Political Quarterly, 64: 6-23

Ramsay, H., Scholarios, D. and Harley, B. (2000), 'Employees and high performance work systems: testing inside the black box', British Journal of Industrial Relations, 38, 4: 501-531

Sisson, K. (1993), 'In search of HRM', British Journal of Industrial Relations, Vol. 31, 2: 201-210

Stewart, M. (1983), 'Relative earnings and individual union membership in the UK’, Economica, 50: 111-25

White M., Hill S, C. Mills and Smeaton, D. (2004). Managing to Change? British Workplaces and the Future of Work, Basingstoke: Palgrave Macmillan.

Willman, P. and Bryson, A. (2006), ‘Union organization in Great Britain’, Journal of Labor Research, forthcoming.

Willman, P., Bryson, A. and Gomez, R. (2006a), 'The long goodbye: the fall of union voice in Britain’, mimeo.

Willman, P., Bryson, A. and Gomez, R. (2006b), 'The sound of silence: which employers choose 'no voice' and why?', Socio-Economic Review, 4: 283-299

Woodland S. (2003). Second Work-Life Balance Survey: Results from the Employers' Survey, London: Department of Trade and Industry. 